解 説

\title{
ネフェライトその後
}

明石 雅夫

（社）粉体粉末治金協会䫏問，干 206-0012 多摩市貝取 2-8-4-9.

\section{Neferrite Part II}

\author{
Tsuneo Akashi \\ Adviser of Japan Society of Powder and Powder Metallurgy, 2-8-4-9 Kaidori, Tama 206-0012.
}

Received February 12, 2004

\section{1 はじめに}

ネフェライトは, 超多重長距離電話搬送装置の滤波器用線 輪および変成器の磁心を画期的に小型化するために日本電気 株式会社で開発された通信用低損失MnZnフェライトですが， ネフェライト開発の経緯については,「ネフェライト」と題し て本誌 48 巻 10 号に発表しました。

ネフェライト開発は

(1) 画期的な性能の通信用 $\mathrm{MnZn}$ フェライトを開発する.

(2) そのフェライトを量産可能とするための原料・設備を開発 する。

(3) 研究成果の権利を確保するための特許を取得する.

の3 点に研究を集中し, 研究速度を速めるため,

(4) なぜ?どうして?を追及する研究は極力排除する.

(5) 通常のステップで必要とする実験でも，思考実験を多用 し，可能と判断すれば省略する.

ことを指針としました.

ネフェライトの原料として使用する高純度酸化鉄の開発を お願いした京都大学理学部化学教室金相学研究室の高田先生 (利夫, 当時助手, 後に京都大学教授 - 化学研究所所長 - 名誉 教授，当協会 10 代会長，故人) と，研究・開発の手法で年中 論争していたことは，先の小文「ネフェライト」にも書きま したが，その原因は(4)(5)ありました.湿式法による酸化鉄 を探求する学問の第一歩として, ネフェライトの原料として 使用する高純度酸化鉄の開発を取り上げられた高田先生が(4) (5)の指針を認める筈が無く,論争が続いたのも無理ありません. しかし, 3 人で始めたネフェライトの研究を,研究着手後 3 年 で量産試作を含めて完了し，その後半年で量産工場を運転す るまで速度を速めることが出来たのは，(4)(5)の指針があった 為だと今でも考えています. 当時の私どもには，優れた材料
を早く開発したい，早く量産したいという思いだけがあり， 学問をするつもりは全くありませんでした。

そういう私に，学位の話が飛び込んで来たのは，昭和 35 年 9月初めのことでした. 石川さん(義興, 当時日本電気株式会 社研究所第一研究室室長, 後東北金属工業株式会社 (現, 株式 会社NECトーキン) 常務取締役, 故人)に呼ばれ，『小林さん (正次, 当時日本電気株式会社専務取締役研究所所長, 後慶應 義塾大学教授, 防衛庁研究所顧問, 故人)が, 岩瀬先生(慶三, 当協会初代会長で, 既に京都大学教授・東北大学教授を定年 退官され東北大学名誉教授になられてはいましたが，高純度 酸化鉄の開発をお願いした時京都大学理学部化学教室金相学 研究室で助手であられた高田先生を指導されていた教授. 故 人)にお目にかかり，君の学位についてお願いしたところ, 即 座に引き受けてくださった. 先生のご都合を司った上で，な るべく早く先生にお目にかかるように。』といわれました。

多賀高等工業学校を卒業後, 直ちに海軍技術見習尉官とな り，敗戦後海軍技術中尉で復員し，日本電気株式会社に入社 した私は，高田先生に高純度酸化鉄の開発をお願いするまで 大学には全く縁が有りませんでしたので, 学位など考えたこ とも無かったのですが，とにかく有難いお話なので，『はい』 と申し上げて石川さんの前から引き下がりました。

\section{2 学位論文作成の経緯}

2.1 初めて岩瀬先生と一対一で

岩瀬先生に直接電話を差し上げるのは恐れ多いので, 高田 先生に電話して事情を話し, 岩瀬先生のご都合を伺って戴い た. 早速高田先生から返電があり，先生は明日東京に出張さ れ，お宿を神田学士会館にとられた。明後日午後 5 時学士会 館に先生をお訪ねするようにとのことでした。 
岩瀬先生にはそれまでも度々お目にかかってはいました。 しかし，小林さん・石川さんのお供の時は，小林さんや石川 さんの後ろでただ頭を下げるだけで直接お話しすることはあ りませんでしたし，一人で京大に出張した時にも，高田先生 とご一緒に先生のお部屋に伺い，酸化鉄の件で高田先生と打 ち合わせに参りましたとご挨拶するたけで，ろくにお話をし たことが無かったほど，岩瀬先生は雲の上の人でした。

当日はかなり緊張して午後 4 時 58 分先生のお部屋の扉を ノックしました.椅子を勧められ，恐縮して座に就いた私に， 先生は，いきなり，『理学博士を望むのか，それとも工学博士 が欲しいのか?』と拨ねになりました、『大学に入っても居 ない私には，理学博士は恐れ多いです. 出来れば工学博士を お願いいたします.』と答えると,『では，そうすることにし て，何かネフェライトに関して書いたものを持って来たか.』 と仰いました.フェライトグループに配属された大卒の新人 用に作ってあった『ネフェライトについて』と題するかなり 分厚い資料をお見せしましたところ，先生は目次と最初の数 ページに目を通された後,『明日同じ時間にまたここに来なさ い.それまでに目を通しておくから，資料はおいてゆきなさ い.』と仰いました、私は『お願いいたします.』と挨拶して 草々に退空しました。

これで岩瀬先生との第一回の一対一面談は終わりました. 廊下に出て大きな息をしたとき脇の下に冷や汗がビッショリ だったことを，昨日のことのように思い出します。

2.2 岩瀬先生との二度目の一対一

翌日同時刻再度先生をお訪ねしました。先生はかなり上機 嫌で，『なかなか良く出来ている，論文の形式になるように， 章・節を改め，言葉も諭文にふさわしいように書き直しなさ い. その際，ネフェライトが使用されている装置の概要・装 置小型化の際に要求されるフェライトの特性・ネフェライト によるフェライト特性の向上がどの程度の装置小型化を実現 したか・その装置小型化によってどのような効果が生まれた か等について詳細に書きなさい。この凟料にも一応は触れて はいるが簡略に過ぎる.日電内では常識なのかもしれないが， これでは世間の人には理解できない，別に一章を設けるのが 良いだろう.』と仰いました。

いかなる難題が出てくるのかとビクビクしていましたのに， 意外に容易なお話に安堵して、『すぐ，書き直します．しかし， この資料は社内文書で，末公表のノー八ウがかなり沢山書か れています。特許で保護できない未公表部分は削除または簡 略化を必要としますが,お許し戴けますでしょうか.』と申し 上げました。

『公表を憚る部分の削除簡略化はやむを得まい.どのくらい 掛かるかね?』『週間もあれば書き直せると思います.』『急 ぐ必要はない．急ぐよりは完全なものにすることを心挂けな さい.出来たら連絡しなさい. 連絡の際，いちいち他人を煩 わすことはないから，君がここに電話しなさい.』と連絡先の 電話番号を教えて戴いてここの件は終りました。

その後は，ネフェライト以外に日電でした仕事の説明を致
しました. 広帯域変成器用超高透磁率パーマロイの開発・標 準周波数発生装置用音叉材料の開発・大型送信管タングステ ンフィラメントのノンサグ対策・大型送信管のタングステン とニッケルの溶接法改善・大型送信管のタングステン, ニッ ケル，銅接続用ニッケル材質の改善・医療用 X管対陰極製法 の確立・モリブデン板，タングステン線，金を用いた板極管 用グリッドの開発・タングステン線モリブデン線の熱間逆張 力線引法の開発と同上用線引機の設計製作・トリヤ $\left(\mathrm{ThO}_{2}\right)$ 入 りタングステン線製法(特に還元, 成型, 烤結, スエージング, 線引工程の作業条件)確立等々説明を終わった時は,夜もかな り遅くなっておりました。

先生はその間夕食を採ろうともされずに，何度も領きなが ら聞いて下さいました.『ネ一ベンとしてはどれも使えそうだ が，まず主論文を書き上げた後としよう。では連絡を待って いる.』というお言葉で, 先生との第二回目の一対一面談を終 わりました。

『先生，夕食をこ一一緒させていただけませんか。とお誘い する勇気は，当時の私にはありませんでしたから,『ありがと う御坐いました.』と頭を下げただけで，退室いたしました。 2.3 工学博士断念

次に岩瀬先生にお目にかかったのは京都の生産開発科学研 究所(以下生研という)でした. 先生は持参した論文の原稿を 開きもせず,『ひどく薄くなったな，もう少し量を增やせない か.』とおっしゃいました.『公表を憚る部分を一部削除一部 簡略化した結果こうなりました。これ以上量を增そうとすれ ば，蛇足を加えて水増しするだけで，中身はどんどん薄くな ります.』と申し上げると,『そうか.』と一言漏らされただけ で，しばらく考え込んでおられました。

やがて，先生は，『主論文がこの量では，工学博士はとても 無理だ、断念するほかあるまい.』と申されて，また考え込ん でしまわれました、私は『申し訳ありません.』と申し上げた だけで，うつむいていました。

その状態がかなり長い時間続いた後，先生は『君の $\mathrm{CaO}$. $\mathrm{SiO}_{2}$ 同時添加による電気抵抗增加の効果は, $\mathrm{MnZn}$ フライト だけの現象か?それとも，他のフェライトにも存在する現象 か?』とお尋ねになられました。

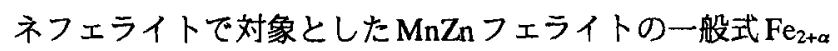
$\mathrm{Mn}_{1-\beta} \mathrm{Zn} \gamma \mathrm{O}_{2 \pm \delta}(\alpha \beta \gamma \delta$ は正の数, $\alpha-\beta+\gamma=0)$ を紙に書きなが ら，『 $\mathrm{Fe}_{2+\alpha}$ である限り， $\mathrm{Mn} \cdot \mathrm{Zn}$ を他のどのような 2 価金属で 置き換えたフェライトにも, $\mathrm{CaO} \cdot \mathrm{SiO}_{2}$ 同時添加による電気抵 抗増加効果は認められる筈です， $\alpha$ がゼ口または負数である 場合にも同様な効果は存在する筈ですが，この場合はもとも とのフェライトが絶縁体で電気抵抗が非常に高いので, $\mathrm{CaO}$ $\mathrm{SiO}_{2}$ 同時添加の効果を実際に確認することはかなり困難だと 思います.』と申し上げました。

先生は間髪を入れず『では， $\mathrm{Fe}_{2+\alpha}$ の場合の各種フェライト にCaO- $\mathrm{SiO}_{2}$ 同時添加による電気抵抗增加の効果が存在するこ とを，実験によって証明しなさい.』と申されました。『はい.』 と答えますと，『1ヶ月以内に結果をまとめて報告しなさい。 
待っている.』との仰せでした.

先生のお言葉の真意が理解できないまま先生のお部屋を出 た私は，その足で京大に高田先生を訪ねました。話を聞いた 高田先生は『书っちゃん，理学博士を考えているかも知れ ん.』といわれました.(恐れ多いことですが，私共はかげで 岩瀬先生のことを古っちゃんと称していました.)しかし，理 学部での研究のやり方を知らない私には，高田先生の言葉の 意味も理解できませんでした。

その夜；高田先生と酒を飲み，いつものように何筒所加梯 子をしましたが,少しも醉えなかったことを記憶しています。 2.4 理学博士への挑戦

前回から 27日目に, $\mathrm{Mn}$ フェライト・Niフェライト・Znフェ ライト・Mg フェライト・MnMg フェライト・NiZn フェライト に微量の $\mathrm{CaO} \cdot \mathrm{SiO}_{2}$ を同時に添加した場合にも, $\mathrm{MnZn}$ フェラ イトの場合と同様に電気抵抗増加の効果が存在することを示 すデータ1)，並びに Ba・SrにはCaより更に微量で Ca と同様な 効果があることを示すデータ ${ }^{1)}$ を携えて，再度生研に岩瀬先 生をお訪ねしました。

一応の説明と共にお示ししたデー夕を，先生は二度も三度 も繰り返しこ覧になった後、『よし、これで $\mathrm{CaO} \cdot \mathrm{SiO}_{2}$ 同時添 加による電気抵抗增加効果か，鉄過剽型フェライトの全てに 認められる共通現象であることが良く分かった。これを基礎 にすれば,理学博士請求のための論文が作れるかも知れない． しかし，そのためには従来やっていなかったような新しい実 験をやる必要が出てくるが, やるか？』と問われました．

理学部の学位論文が如何なるものであるかを知らないまま， 『やらせて下さい.』と申し上げました。盲人蛇に怖じずとは よく言ったもので，これがその後の苦難の発端であり，同時 に理学部での学問研究の片䚬に触れる端緒でもありました。

先生は, $\sqrt{ } \mathrm{CaO} \cdot \mathrm{SiO}_{2}$ 同時添加による電気抵抗增加効果か なぜ起こると考えるか？』と質問されました．

『フランスの Guillaud が $0.05 \sim 0.25 \mathrm{~mol} \%$ の CaO を添加する ことによって渦電流損失の少ない $\mathrm{MnZn}$ フェライトを得るこ とに成功したと称した時, 彼は高い比抵抗を持つ $\mathrm{Mn} \cdot \mathrm{Ca}$ 化合 物を主体とする固溶体が結晶粒界に析出することがその原因 だと推定しています.

Guillaud は $\mathrm{CaO}$ を単独に添加することによってこのような 現象が起きると考えていますが， $\mathrm{CaO}$ のの添加ではこのよ うな現象は生じません.Guillaudが実験で使用した酸化鉄原料 は高純度玉然葆酸鉄で，その天然蓚酸鉄は確かに高純度では ありましたが僅かに $\mathrm{SiO}_{2}$ を含んでいる事実を, Guillaudの指 導で通信用低損失 MnZn フェライトを作っているL.C.T.のパ リー工場で昨年確認しました。

Guillaud が $\mathrm{CaO}$ の添加効果と認識していた現象は，私ども の $\mathrm{CaO} \cdot \mathrm{SiO}_{2}$ 同時添加による電気抵抗增加効果と同じ現象で， 彼は添加した $\mathrm{CaO}$ と原料として用いた高純度玉然蓷酸鉄中の $\mathrm{SiO}_{2}$ との複合効果であることに気付かず， $\mathrm{CaO}$ 単独の添加効 果と誤認したに違いありません。

抵抗增加の効果があるのが $\mathrm{MnZn}$ フェライトだけではない
ことから, Guillaud が高い比抵抗を持つ $\mathrm{Mn} \cdot \mathrm{Ca}$ 化合物を主体 とする固溶体といっている部分を, $\mathrm{CaO} \cdot \mathrm{SiO}_{2}$ を主体としフエ ライトを固溶した高い比抵抗を持つ薄層と修正し，この薄層 が結晶粒界に析出することが電気抵抗増加の原因と推定して います.』と答えました。

先生は更に『Guillaudはその推定を証明したか?』と質問さ れましたので,『Guillaudは $\mathrm{CaO}$ が結晶粒界に集中しているこ とを証明したと称していますが, 結晶粒界に高抵抗薄層が存 在することは証明しておりません，ただ推定しているたけで す。また Guillaud 以外にも，そのような証明をした人を知り ません.』と答えました。

間髪を容れず，先生はいとも簡単に『では，その推定が真 実であると，君が証明しなさい，連絡を待っている.』と申さ れ、『はい』と答えた私を部屋に残したまま，席を立たれまし た。その日はそれで終わりでした。

高田先生は, 『やはりそうか. 理学博士となると, 今日の難 題はまだ序の口で，次から次と難題が続く，覚悟したほうが いい.』と叠かしますが,これが理学部流の研究かと覚悟を決 めた私は，その夜の高田先生との梯子酒に気持ちよく醉った 記憶があります。

2.5 高抵抗首が結晶粒界に存在することの証明 (その 1 )

$\mathrm{Fe}_{2.06} \mathrm{Mn}_{0.6} \mathrm{Zn}_{0.34} \mathrm{O}_{4+\delta}$ の組成を持つ $\mathrm{MnZn}$ フェライトに微量の $\mathrm{CaO} \cdot \mathrm{SiO}_{2}$ を同時に添加した試料の中から, $10 \mu$ 程度のほぼ均 一な結晶からなる組織を持つ試料即ち $\mathrm{SiO}_{2} 0.02 \mathrm{~mol} \%$ と $\mathrm{CaO}$ $0.2 \mathrm{~mol} \%$ 或いは $0.5 \mathrm{~mol} \%$ とを同時に添加した 2 試料と，それ より遥かに巨大に成長した多くの結晶を含む組織を持つ試料 即ち $\mathrm{SiO}_{2} 0.05 \mathrm{~mol} \%$ と $\mathrm{CaO} 0.1 \mathrm{~mol} \%$ 或いは $0.2 \mathrm{~mol} \%$ とを同時 に添加した 2 資料計 4 試料を選び， $1 \mathrm{KHz} / \mathrm{sec}$ から $30 \mathrm{MHz} / \mathrm{sec}$ の周波数範囲で電気抵抗と誘電率の変化を測定しました.そ の結果, $\mathrm{SiO}_{2} 0.02 \mathrm{~mol} \%$ を含み均一な微結晶組織を示す 2 試料 の電気抵抗と誘電率は測定周波数の增加に伴って緩やかな dispersion を示し, $\mathrm{SiO}_{2} 0.05 \mathrm{~mol} \%$ を含み多くの巨大結晶のあ る結晶組織を示す 2 試料の電気抵抗と誘電率は測定周波数の 増加に伴って急激なdispersionを示すことが明らかとなりまし た.

この様に $\mathrm{SiO}_{2}$ 添加量の差によって結晶組織が異なるだけで なく, 測定周波数の増加に伴う電気抵抗と誘電率の dispersion の样式が異なる典型的な 2 種類各 2 試料計 4 試料について, 結 晶粒界に極めて薄く且つ高比抵抗をもつ層が存在するという モデルを仮定して誘導された式を用い，結晶粒内の比抵抗を 結晶粒界の高抵抗薄層それに比し無視できるとし，また誘電 率 $\varepsilon$ を 10 として解析しました。

その結果, $\mathrm{SiO}_{2} 0.02 \mathrm{~mol} \% \mathrm{CaO} 0.2 \mathrm{~mol} \% \mathrm{t}$ を添加した試料で $6 \times 10^{5} \Omega-\mathrm{cm}, \mathrm{SiO}_{2} 0.02 \mathrm{~mol} \% \mathrm{CaO} 0.5 \mathrm{~mol} \%$ を添加した試料で $2.2 \times 10^{5} \Omega-\mathrm{cm}, \mathrm{SiO}_{2} 0.05 \mathrm{~mol} \% \mathrm{CaO} 0.1 \mathrm{~mol} \%$ を添加した試料で $2.2 \times 10^{6} \Omega-\mathrm{cm}, \mathrm{SiO}_{2} 0.05 \mathrm{~mol} \% \mathrm{CaO} 0.2 \mathrm{~mol} \%$ を添加した試料で $2.5 \times 10^{6} \Omega-\mathrm{cm}$ の比抵抗を持つ薄層が結晶粒界に存在するとす

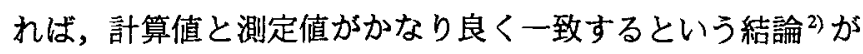
得られました。 
$\mathrm{SiO}_{2}$ 添加量の差によって結晶組織が異なるだけでなく，測 定周波数の增加に伴う電気抵抗と誘電率のdispersionの梯式が 異なる典型的な 2 種類各 2 試料計 4 試料に対し，結晶粒界に高 い比抵抗をもつ薄層が存在するというモデルを仮定して誘導 された式を用い，実験值をほほ説明できる計算結果が得られ たのですから，結晶粒界に高抵抗薄層が存在するという推定 は証明できたと(その時は)考えました.その結果を持って岩 瀬先生を神田の学士会館にお訪称したのは前回から約半月後 でした。

『思いのほか早かった.』と機嫌良く迎えて下さった先生は， 結果の説明が進むに連れてだんだん険しいお顔になられまし た. 遂には説明を途中で遮られて,『これは証明ではない. 自 分に都合の良いモデルを仮定して導いた式に適当な数値を代 入して計算したら，実駼結果に近い結果が得られたというに 過きないのであろう，見て来たような仮定の下で作られた式 に適当な数値を代入して計算した結果がいかに実験值と一致 したからといっても，仮定したモデルが真実であると証明する ことは出来ない，それは，高々仮定したモデルが本当らしい ということが出来るだけで，この様な方法では高抵抗薄層が 結晶粒界に存在するという推定が正しいということを証明す ることは絶対に出来ない，要求したのは，高抵抗薄層が結晶 粒界に存在するという推定が真実であると，実験事実のみで 証明ことである.それが出来ない限り，今後の連絡は一切無 用である.』と仰ったまま私の顔を睍み付けられました。

私は，実験事実のみで証明するための準備が進行している と説明することも出来ず，『分かりました.』とのみ申し上げ てお部屋を辞去するほかありませんでした．

この日, 岩瀬先生から非常に強く叱られましたが, 帰途に 就いた私は，決して落ち込んではいませんでした。岩瀬先生 が証明といわれる実験そのものの準備がかなり進んでいたか らです.今度こそ絶対先生に『参った.』と言わせて見せる。 そのような気持ちで，研究室に戻りました。

2.6 高抵抗層が結晶粒界に存在することの証明 (その 2)

進んでいた実験の準備とは, Bridgman 法による単結晶作成 の条件を変更し, 単結晶ではなく二個の結晶からなるフェラ イト棒を作る条件を見出すことでした。

まだ100\%確実に二個の結晶からなるフェライト棒を作る条 件は確立していませんでしたが, モテルを仮定して作った式 を計算する手法が先生の挍気に召さぬ以上，事を急きます。

直ちに, 高純度原料を用いた $\mathrm{Fe}_{2.08} \mathrm{Mn}_{0.59} \mathrm{Zn}_{0.33} \mathrm{O}_{4+\delta}$ の組成を持 つ $\mathrm{MnZn}$ フェライト・これに $\mathrm{CaO} 0.1 \%$ を加えた組成・ $\mathrm{SiO}_{2}$ $0.01 \%$ を加えた組成・ $\mathrm{CaO} 0.1 \%$ と $\mathrm{SiO}_{2} 0.01 \%$ を同時に加えた 組成の 4 種類の組成を持つ $\mathrm{MnZn}$ フェライトの二個の結晶か らなるフェライト棒を作る実験に着手しました。結局 6 回の 実験で 4 種類の組成を持つ $\mathrm{MnZn}$ フェライトの二個の結晶か らなる直径 $1 \mathrm{~cm}$ のフェライト棒を作ることができました．

高さ $2 \mathrm{~cm}$ の円柱を切り出し, 結晶粒界をはさんで円柱の両 側面に電力端子を取り，端子間隔を種々に変えた電圧測定端 子により，4端子法によって抵抗を測定しました。結晶粒界の
極く近傍に電圧端子の一方の端子を置き他の端子を結晶粒界 をはさんだ他の粒子内に置いて測定した結果が Fig.13)です。 電圧端子の最も狭い間隔は $10 \mu$ 程度でした. Fig.1には CaOと $\mathrm{SiO}_{2}$ を単独で添加したデータが示されていませんが, 高純度 原料を用いた場合と殆ど同様でしたので省略しました。

結晶粒内の比抵抗は $\mathrm{CaO} \cdot \mathrm{SiO}_{2}$ の有無にかかわらず何処でも $0.23 \Omega-\mathrm{cm}$ でしたから,電圧測定端子の両端子が同一結晶粒内 にある時は極めて低い電圧を示していますか，一方の端子が 結晶粒界を越えるや否や第一図に見られるように高い電圧を 示す事実から，Fig.1は，結晶粒界に存在する高抵抗薄層と電 圧測定端子の端子間隔が大きくなるにつれて結晶粒内の低抵 抗層 $(0.23 \Omega-\mathrm{cm})$ の寄与度が増加することによって得られたと 理解することが出来ます.結晶粒界の高抵抗薄層の厚さを $0.1 \mu$ と仮定すれば薄層比抵抗は $5 \times 10^{3} \Omega-\mathrm{cm}$, 高抵抗薄層の厚さを $0.01 \mu$ と仮定すれば薄層比抵抗は $5 \times 10^{4} \Omega-\mathrm{cm}$, となります.

高純度原料を用いた $\mathrm{MnZn}$ フェライトの結晶粒界にも多少 抵抗の高い層があることをFig.1は示していますか，高純度原 料を用いた場合でも $\mathrm{CaO} \cdot \mathrm{SiO}_{2}$ が皆無ではないための現象か， それともの結晶粒界固有の現象かは明らかでありませんが， $\mathrm{CaO} \cdot \mathrm{SiO}_{2}$ 添加の有無による差は明瞭です.

この結果を持って生研に先生をお訪ねしたのは, 前回お叱 りを受けてから 4 週間後の12月中旬でした. 初めあまり気乗

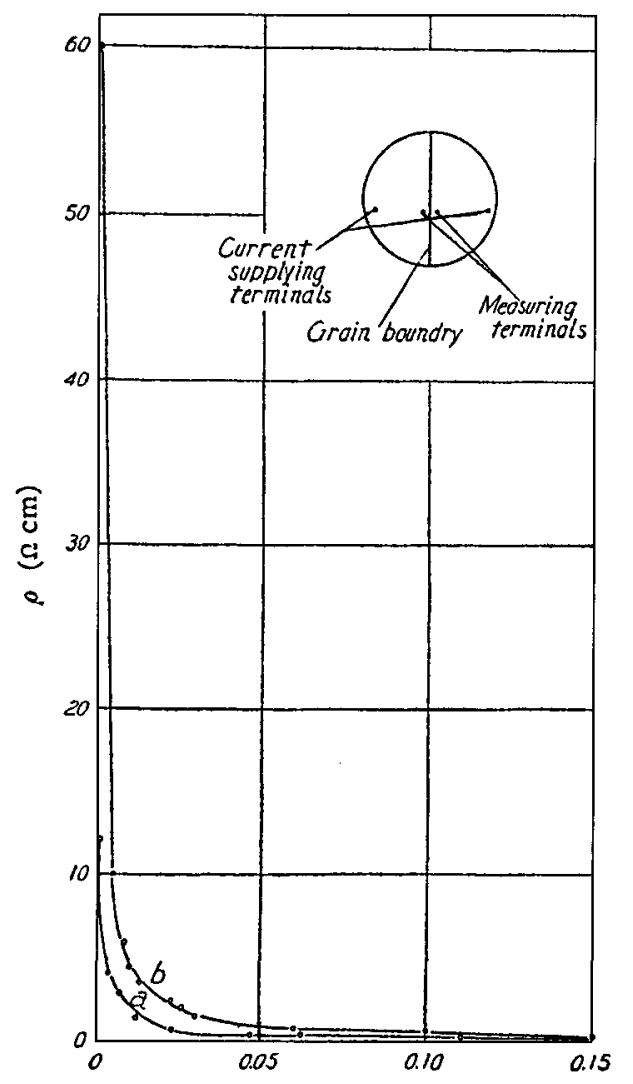

Interval between measuring terminals $(\mathrm{cm})$

Fig.1 Resistivities as the function of the interval. a: No impurity, b: $\mathrm{CaO} 0.1 \mathrm{~mol} \%, \mathrm{SiO}_{2} 0.01 \mathrm{~mol} \%$ 
りがしないご様子であられた先生は, 外周と切断面をエッチ ングして二個の結晶からなることが明瞭な直径 $1 \mathrm{~cm} の \mathrm{MnZn}$ フェライト棒をお見せした時には, 明らかにご様子が変わら れました.これに向き合う切断面を研磨した高さ $2 \mathrm{~cm}$ の柱 (外周はエッチングしてあるが, 切断面は研磨のまま)に電流 端子を取り付けた測定試料と,4端子抵抗測定法用電圧測定端 子の数個の実物をご覧に入れながら, Fig.1を示して説明しま すと,『よし.これで結晶粒界に高抵抗薄層が存在することを 疑問の余地無く証明できた.』と合格点を下さいました.

後は, 電圧測定端子の作り方を細かく質問され, 端子間隔 が大きい場合には 2 本の木綿針の先端を残してポリエステル で固め, 端子間隔の小さい場合には, 絹針を先端の極一部を 残してポリエステルに埋め片側から研磨して針を半分に切断 しものを 2 個作って組み合わせ, 間に挟んだ雲母の上部の厚 さを加減して端子間隔を調節した後ポリエステルで固めたこ とを申し上げると, 『君は思いもよらず器用だね.』と褒めて 下さいました. 81 年生きて来ましたが, 後にも先にも器用と 言われたのは,これが最初で最後です.

先生は最後にはひどくご機嫌ではありましたが, そのまま 終わるはずはありません.『結晶粒界の高抵抗薄層は Ca・Si 主体とする固溶体が結晶粒界に析出することで出来るという 話だが, 結晶粒界に $\mathrm{Ca} \cdot \mathrm{Si}$ が集中していることを, 次回まで に証明しなさい.』と次の宿題が出されて, 終わりました.

その夜も例のように高田先生と梯子酒でしたが, この夜は 可知先生 (祐次, 当時京都大学教授, 後に京都大学名誉教授, 故人) がこ一一緒でした. 3 人とも大正 11 年の生まれで, 可知 先生が 8 月, 私が9月, 高田先生が 10 月生まれという順で, 仲 がよ, 東京では可知先生が東北大学助教授の時代から酒席 をご一緒にしていましたが, 京都で可知先生とお酒を飲むの は初めてでした. その夜は 3 人で楽しく酔って過ごしました. 2.7 液相焼結

現在のようにE.P.M.A.がどの研究室にも備わっている時代 ならば, $\mathrm{Ca}, \mathrm{Si}$ が結晶粒界に集中していることを証明するの に, 苦労は要らないでしょう. 先に結晶粒界に高抵抗薄層か 存在することを証明する時使用した高純度原料を用いた MnZn
フェライト・これに $\mathrm{CaO} 0.1 \%$ を加えた組成・ $\mathrm{SiO}_{2} 0.01 \%$ を加 えた組成・ $\mathrm{CaO} 0.1 \%$ と $\mathrm{SiO}_{2} 0.01 \%$ を加えた組成の 4 種類の組 成を持つ $\mathrm{MnZn}$ フェライトの二個の結晶からなるフェライト 棒の断面を, E.P.M.A.で走查すれば所要の結果が得られるに 違いありません.

しかし，当時はそんな便利な装置はまだ存在していません でした. 仕方がありません， Ca が結晶粒界に集中している証 拠として ${ }^{45} \mathrm{CaO}$ を用いたGuillaudと同様な方法を利用すること にしました。

ただし，Guillaud が ${ }^{45} \mathrm{CaO}$ を用いて Ca が結晶粒界に集中し ている証拠として示した写真は, 一面に黒い斑点が散乱して いるだけで, どうしてこの写真が Caが結晶粒界に集中してい る証拠になるのだろうかと, 首を傾げたくなるような写真で した.この程度の写真で岩瀬先生がウンとおっしゃる訳があ りませんから, 誰が見てもCaが結晶粒界に集中しているとい う写真を作らなければならないと覚悟は致しました.

放射能を持つ ${ }^{45} \mathrm{CaO}$ は普通の実験室で簡単に扱うというわ けには参りませんで, 適当な設備を施した実験室が必要でし た. 幸いなことに当時, フェライト原料中の極微量な不純物 を定量分析する究極の手法と考えられていた中性子放射化分 析の技術を取得するために, フェライトグループの一員で あった小野田儀弘君を東海村の原子力研究所に派遣していま したので，彼にその実験を命じました．

実験は, $\mathrm{Fe}_{2.08} \mathrm{Mn}_{0.59} \mathrm{Zn}_{0.33} \mathrm{O}_{4+\delta}$ 組成の $\mathrm{MnZn}$ フェライト仮焼粉 末を小野田君に届け, これに $\mathrm{CaO}$ と $\mathrm{SiO}_{2}$ を添加し, $\left(\mathrm{Fe}_{2.08} \mathrm{Mn}_{0.59}\right.$ $\left.\mathrm{Zn}_{0.33} \mathrm{O}_{4+\delta}\right)_{0.9989}(\mathrm{CaO})_{0.001}\left(\mathrm{SiO}_{2}\right)_{0.0001}$ と $\left(\mathrm{Fe}_{2.08} \mathrm{Mn}_{0.59} \mathrm{Zn}_{0.33} \mathrm{O}_{4+\delta}\right)_{0.999}$ $(\mathrm{CaO})_{0.001}$ で示される 2 種類の $\mathrm{MnZn}$ フェライト粉末を作ると き, $\mathrm{Ca}$ の一部を ${ }^{45} \mathrm{Ca}$ に置換した粉末を作り, 成型焼結しまし た. 焼結の条件は結晶粒子を成長させるため $1,550^{\circ} \mathrm{C} 2$ 時間

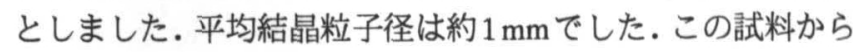
切り出した試料の一面を鏡面に研磨して $0.5 \mathrm{~mm}$ 以下の薄片を 作り, 鏡面に研磨した面を写真乾板の上に置き, オートラジ オグラフを作成しました. オートラジオグラフ作成後, 試料 をエッチングして顕微鏡写真を撮影しました.

$\mathrm{CaO}$ と $\mathrm{SiO}_{2}$ とを共に含む試料のオートラジオグラフと顕微

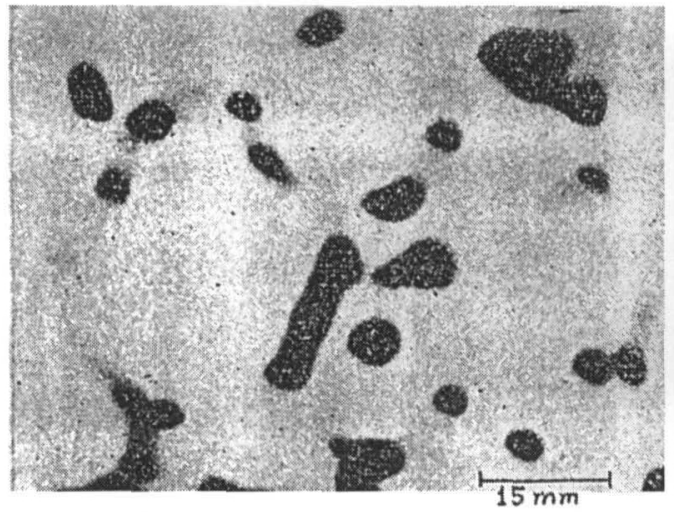

(a) Autoradiograph.

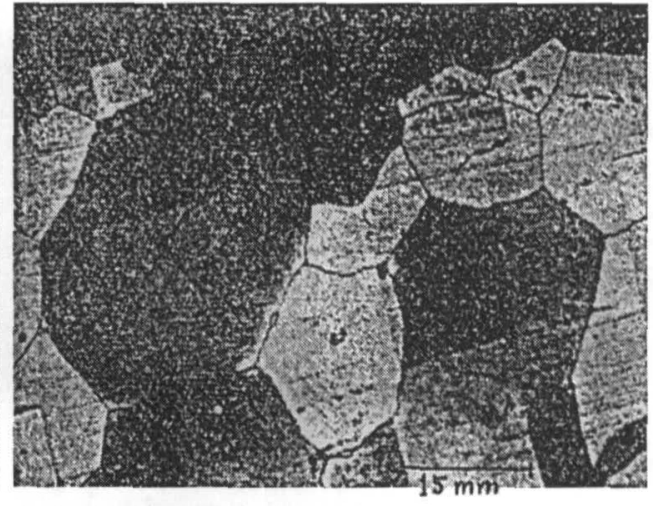

(b) Corresponding texture.

Fig.2 Grain-boundary autoradiograph (a) and corresponding texture (b) in $\mathrm{MnZn}$ ferrite with small amounts of $\mathrm{SiO}_{2}$ and $\mathrm{CuO}$. 


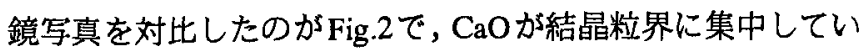
る様子が見事に示されています4).

CaOのみを含む試料でも同様の実験を行ないましたが，そ のオートラジオグラフは全体がぼんやりと黒くなるだけで， 結晶粒界への CaOの集中は認められませんでした. Fig.2とあ わせ考えれば, $\mathrm{SiO}_{2}$ が $\mathrm{CaO}$ の結晶粒界集中に決定的な役割を 果たしていることは極めて明白です。

これらの結果を携えて岩瀬先生にお目にかかったのは昭和 36 年正月中旬の生研でした.一応の説明の後, $\mathrm{SiO}_{2}$ が結晶粒 界に集中している事実を直接証明するする手段が見つからな いことをお詑び申し上げると，先生は『まあいいだろう.』と 許して下さいました。

次回までの宿題は, $\mathrm{CaO} 0.1 \% \mathrm{SiO}_{2} 0.01 \%$ という極めて微量 の添加にも拘らず，なぜ $\mathrm{CaO}$ と $\mathrm{SiO}_{2}$ がこの様に全域の結晶粒 界に分布するのか，その理由を明らかにせよ．ということで した.

この頃には，次に先生がどのような課題を出されるか，見 当がつくようになっていましたので, 今回の宿題についても 既に手は打ってありました。

その夜も，例のように高田先生, 可知先生との梯子酒でした. 2.8 液相焼結

既に着手済みの実験とは, $\mathrm{Fe}_{2} \mathrm{O}_{3} \cdot \mathrm{CaO} \cdot \mathrm{SiO}_{2}$ と $\mathrm{MnZn}$ フェラ イト・ $\mathrm{CaO} \cdot \mathrm{SiO}_{2}$ の3 元セラミックスの $10 \%$ 刻みの各組成の融 点測定です. 融点測定といっても本格的な測定ではなく，隙 間を開けて逆円錐状に巻き上げた白金線の容器を20個ほどふ ら下げた鉄枠を作り，白金線の容器にそれそれ組成の異なる

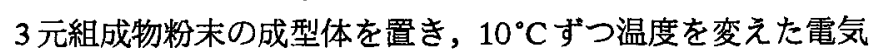
炉に鉄枠こと出し入れし,成型体が溶けて無くなっていれば， その温度をその組成物の融点とする乱暴な測定法です。

$\mathrm{Fe}_{2} \mathrm{O}_{3} や \mathrm{MnZn}$ フェライトが $10 \%$ で，残り $\mathrm{CaO}$ と $\mathrm{SiO}_{2}$ でや や $\mathrm{SiO}_{2}$ が多い組成物が $1,000^{\circ} \mathrm{C}$ 以下の融点を示すことが既に 分かっていました．その近傍のより細かい組成での融点測定 も既に進行中でした。

実験の進行を待って, $\mathrm{Fe}_{2} \mathrm{O}_{3} \cdot \mathrm{CaO} \cdot \mathrm{SiO}_{2}$ および $\mathrm{MnZn}$ フェラ イト・ $\mathrm{CaO} \cdot \mathrm{SiO}_{2}$ を 3 頂点とする 3 元状態図用の 2 枚の用紙に それぞれの組成の融点を $10^{\circ} \mathrm{C}$ 刻みで地図の等高線のように示 した図を作成しました。

また，直径約 $3 \mathrm{~cm}$ 高さ約 $2 \mathrm{~cm} の \mathrm{Fe}_{2.08} \mathrm{Mn}_{0.59} \mathrm{Zn}_{033} \mathrm{O}_{4+8}$ 組成を 持つ高純度原料を用いたフェライト焼結体の上面中心に， $\mathrm{CaO} \cdot \mathrm{SiO}_{2} \cdot \mathrm{MnZn}$ フェライトの3元セラミックス中最も融点の 低かったセラミックスの $1 \mathrm{~mm}$ 程度の焼結体小粒を置き，每時 $100^{\circ} \mathrm{C}$ 速度で $1200^{\circ} \mathrm{C}$ まで昇温し, $1200^{\circ} \mathrm{C}$ 到達直後冷却し た試料を真二つに切断し，溶けた物質が表面に大きく広がっ ているばかりでなく最も深い所では裏面に近いところまで広 がっている状態を示している試料を作成しました。

この試料と図を携えて岩瀬先生を生研にお尋ねしたのは， 前回から 2 週間後の 2 月の初めでした.

2 枚の融点分布を示す 3 元図と, 低融点の $\mathrm{CaO} \cdot \mathrm{SiO}_{2} \cdot \mathrm{MnZn}$ フェライト焼結体が $1,200^{\circ} \mathrm{C}$ 以下の温度で $\mathrm{MnZn}$ フェライト焼
結体に広く拡散している状態が明確なサンプルを示しながら， 『焼結時, 微量 $\mathrm{CaO} \cdot \mathrm{SiO}_{2}$ を含む $\mathrm{MnZn}$ フェライト成形体を加 熱昇温中，拡散によって融点の低い組成となった領域がたま たま各所に出来る可能性は充分考えられます.』

『成形体の温度が $1000^{\circ} \mathrm{C}$ に近つくとこれら低融点領域の組 成物は各所で溶融し，近隣の酸化物粒子の表面を覆いつつ広 がります.』

『融液と接触した酸化物粒子は融液中に溶け込みます。融液 に溶け込んだ $\mathrm{CaO} や \mathrm{SiO}_{2}$ は融液中に留まりますが, 融液に溶 け込んだ $\mathrm{Fe}_{2} \mathrm{O}_{3} \cdot \mathrm{MnO} \cdot \mathrm{ZnO}$ の一部は融液中に留まるものの大 部分は融液中を移行しつつフェライトとして析出します.』

『融液に溶け込んた $\mathrm{CaO} \cdot \mathrm{SiO}_{2}$ より融液に残留した $\mathrm{Fe}_{2} \mathrm{O}_{3}$. $\mathrm{MnO} \cdot \mathrm{ZnO}$ の量が多くなることは容易に考えられますから，そ の場合融液の融点は上昇し, 試料の温度が融液の融点以下で あれば, $\mathrm{CaO} \cdot \mathrm{SiO}_{2}$ を主体とする $\mathrm{Fe}_{2} \mathrm{O}_{3} \cdot \mathrm{MnO} \cdot \mathrm{ZnO}$ の固溶体の 薄風として結晶粒界に固化します.』

『この結晶粒界に固化した薄層は,昇温中の試料の温度が薄 層の融点を超えた時点で再度溶融し，先に述べた状態を繰り 返しながら液相焼結を推進すると同時に，液相が粒子表面を 覆う領域を抬張します.』

『この様な状況は焼結温度が最高保持温度に達するまで続き ますが, 保持温度に達した直後には, 全ての液相は $\mathrm{CaO} \cdot \mathrm{SiO}_{2}$ を主体とする $\mathrm{Fe}_{2} \mathrm{O}_{3} \cdot \mathrm{MnO} \cdot \mathrm{ZnO}$ の固溶体の高抵抗薄層として 結晶粒界で固化します.』

『液相を介する焼結が固体拡散のみによる焼結より速く進行 することは良く知られています. $\mathrm{CaO} \cdot \mathrm{SiO}_{2}$ を含むネフェライ トか，通常の $\mathrm{MnZn}$ フェライトより $200^{\circ} \mathrm{C}$ 近くも低温で烧結 を完了するのは, $\mathrm{CaO} \cdot \mathrm{SiO}_{2}$ を主体とする融液が介在する液相 焼結であるからではないかと考えています。』

『ネフェライトの場合，この様にして，極めて僅かな $\mathrm{CaO} ・$ $\mathrm{SiO}_{2}$ にも拘らず, $\mathrm{CaO} \cdot \mathrm{SiO}_{2}$ を主体とする $\mathrm{Fe}_{2} \mathrm{O}_{3} \cdot \mathrm{MnO} \cdot \mathrm{ZnO} の$ 固溶体の高抵抗薄層かフェライトの全結晶粒界を覆っている のだと考えます.』と一気に説明いたしました．

液相焼結という言葉は，焼結について記した書物や論文に はよく見かけました.しかし，液相焼結の具体例を示した書 物や論文をそれまで見たことはありませんでした．液相焼結 の具体例を初めて見出したという自負心も説明を自信たっぷ りにさせた一因かもしれません.

黙って説明を聞いておられた先生は, 暫くして,『この見て きたような嘘が，10年もったら本物だね.』と申されました。

その後すく、『各種フェライトに $\mathrm{CaO} \cdot \mathrm{SiO}_{2}$ を添加したとき， 電気抵抗のピークが 2 箇所にある場合があった。 その理由は なぜか? また焼結温度・焼結雾囲気を変えるとピークの組成 が変動するのはなぜか？の 2 点を次回には明らかにしなさ い.』と続けられました.

次回の課題を出されたことで，断続しながら液相焼結が進 行することが,極めて僅かな $\mathrm{CaO} \cdot \mathrm{SiO}_{2} に も$ も拘らず, $\mathrm{CaO} \cdot \mathrm{SiO}_{2}$ を主体とする $\mathrm{Fe}_{2} \mathrm{O}_{3} \cdot \mathrm{MnO} \cdot \mathrm{ZnO}$ の固溶体の高抵抗薄層がフェ ライトの全結晶粒界を覆っていることの原因という説明を， 
先生がお認めになられた結果が，『この見てきたような嘘が， 10年もったら本物だ齐.』という先生のお言葉であったことを 理解しました。

また先生は,『次回には, 各種つェライトに $\mathrm{CaO} \cdot \mathrm{SiO}_{2}$ を添 加したとき, 電気抵抗が変化した実験結果を論文にしてきな さい.』と仰しゃられました。

高田先生は，おっちゃんが論文を畫けといったのは難題も そろそろ終わりだというサインだと申され，前祝だと称して その夜の梯子酒はかなり盛り上がりました。

\section{9 結晶粒界高抵抗物質の電気抵抗}

各種フェライトに $\mathrm{CaO} \cdot \mathrm{SiO}_{2}$ を添加したとき, 電気抵抗の ピークが 2 箇所にある場合があった，その理由はなぜか？ま た焼結温度・焼結需团気を変えるとピークの組成が変動する のはなぜか？の2点を次回には明らかにせよ．という岩瀬先 生の課題に答えるためには，結晶粒界を覆っているであるう 高抵抗層の組成と考えられる $\left(\mathrm{CaO}_{1-x} \mathrm{Si}_{\mathrm{x}} \mathrm{O} \gamma\right)_{1-y}(\mathrm{~A})_{\mathrm{y}}$ 但し(Aは， $\mathrm{Mn}, \mathrm{Ni}, \mathrm{Zn}, \mathrm{Mg}, \mathrm{MnMg}, \mathrm{MnZn}, \mathrm{NiZn}$ の各フェライト, と $\mathrm{MnO}$, $\left.\mathrm{NiO}, \mathrm{ZnO}, \mathrm{MgO}, \mathrm{Fe}_{2} \mathrm{O}_{3}\right)$ の各種組成物を温度と雾囲気を変えて 蛄結し，その電気抵抗を測定すれば良いはずです。

この実験は既に殆ど終わりに近く，テータの整理もかなり 進んでいたので，数日で次の結諭，

(1) 微量の $\mathrm{CaO} \cdot \mathrm{SiO}_{2}$ を含む $\mathrm{Mn}, \mathrm{Ni}, \mathrm{Zn}, \mathrm{Mg}, \mathrm{MnMg}, \mathrm{MnZn}$ フェ ライトが焼結需囲気で大きく電気抵抗が変化するのに対 し, 比率を変えた $\mathrm{CaO}$ と $\mathrm{SiO}_{2} や\left(\mathrm{Ca}_{0.85} \mathrm{Si}_{0.15} \mathrm{O}_{\delta}\right) 30 \%$ の残部 を $\mathrm{MnO}, \mathrm{NiO}, \mathrm{ZnO}, \mathrm{MgO}$ とした組成物は焼結雾囲気が大き く変化しても電気抵抗の変化が極めて僅かである.

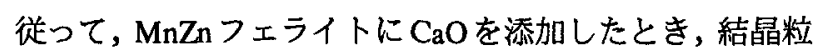
界高抵抗物質として高い比抵抗を持つ $\mathrm{Mn} \cdot \mathrm{Ca}$ 化合物 (実 際は $\mathrm{SiO}_{2}$ も存在していたから, $\mathrm{Mn} \cdot \mathrm{Ca} \cdot \mathrm{St}$ 化合物というぺ きだ)を主体とした固溶体が出来るとしたGuillaudの説は， 明らかに誤りである。

(2) 結晶粒界高抵抗物質か $\mathrm{CaO} \cdot \mathrm{SiO}_{2}$ と $\mathrm{Fe}_{2} \mathrm{O}_{3}$ とから成るとす れば,各種フェライトが焼結雾囲気で大きく電気抵抗が変 化することは説明できるが,フェライトの種類による電気 抵抗の差を説明できない，

(3) 結晶粒界高抵抗物質が $\mathrm{CaO} \cdot \mathrm{SiO}_{2}$ と各種フェライトとから 成るとすれば,各種フェライトが焼結雾囲気で大きく電気 抵抗か変化することや,フェライトの種類による電気抵抗 の差を説明できるから，結晶粒界高抵抗物質は $\mathrm{CaO} \cdot \mathrm{SiO}_{2}$ と各種フェライトとから成る組成物である.

(4) $\mathrm{CaO} \cdot \mathrm{SiO}_{2}$ を含む各種フェライトの電気抵抗がピークに向 けて上昇する側のフェライトがn型半導体であればピーク を越えて下降する側のフエライトは $\mathrm{p}$ 型半導体であり，電 気抵抗がピークに向けて上昇する側のフェライトがp型半 導体であればピークを越えて下降する側のフェライトはn 型半導体である.実験的に立証することは殆ど不可能であ ろうが, $\mathrm{n}$ 型 $\mathrm{p}$ 型の半導体の種類が転換するピークでは恐 らく絶縁物のような高比抵抗值を示すであろう.ピークが 二つある場合も同様である．また，焼成温度・雾囲気に
よってフェライトの抵抗值が変化したりピークを示す組成 が変化するのは, 焼成温度・霝囲気によってn型 $\mathrm{p}$ 型の出 来る組成範囲が変化したり,出来る半導体の性質が変化す るためであろう.

を緾める事が出来ました。

半導体としてフェライトを扱って見ようと考えて，高純度 原料の入手からスタートしたネフェライトの研究は, 高純度 原料を用いた第一回目の実験で損失が極めて大きい $\mathrm{MnZn}$ フェライトしか得られず, 完全に失敗して以来, 半導体の三 文字を完全に忘れてきました.最後に近くなって, $\mathrm{CaO} \cdot \mathrm{SiO}_{2}$ 同時添加によるフェライトの電気抵抗ピークの説明にn型 $\mathrm{p}$ 型 の半導体が必要となったことに，何か因縁めいたものを感じ たものでした.

各種フェライトに $\mathrm{CaO} \cdot \mathrm{SiO}_{2}$ を添加したとき,電気抵抗が変 化した実験結果を論文にするのに若干時間を要しましたが， 結晶粒界高抵抗物質の電気抵抗の奏騟結果を携えて次に岩瀬 先生にお目にかかったのは，2月の下旬学士会館でした.

実験結果について螋々説明を申し上げましたが，先生はこ れに対して特に何も仰しゃられませんでした.

そして先生は，『今日持ってきた論文を「フェライトの粒界 析出物と電気抵抗(第一報)」卓として主論文の第一部とする。 『粉体および粉末治金』の投稿は京都に戻った時にしておく.

$\mathrm{CaO} \cdot \mathrm{SiO}_{2}$ 同時添加によってフェライト電気抵抗が增加する のは，結晶粒界に高抵抗薄層が生成するためで，結晶粒界に 出来る高抵抗薄層がどのような物であり，どうして出来たか などについて，考察を加えて總めた論文を主論文の第二部と

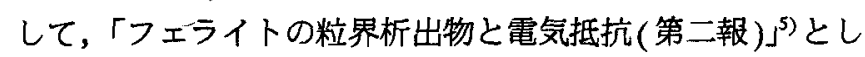
て『粉体および粉末冶金』への投稿とすることにしよう.

主論文の第三部は, $\mathrm{CaO} \cdot \mathrm{SiO}_{2}$ 同時添加によってフェライト の電気抵抗が增加するのは，結晶粒界に高抵抗薄層が生成す るためということを，モデルを用いて解析した結果を英文で 作成し，適当な学会誌に発表する ${ }^{2)}$.

主論文の第四部は, $\mathrm{MnZn}$ フェライトに $\mathrm{CaO} \cdot \mathrm{SiO}_{2}$ を同時に 添加することが，磁気特性及び結晶組織に及ほした影響につ いて，英文にまとめたものを金属学会の英文誌に投稿するも のにするの.

参考論文のその 1 は，二つの結晶の粒界を挟んで電気抵抗 を測定した論文 ${ }^{3}$, その2はオートラジオグラフについての論 文)とし，適当な学会誌に発表する.

以上の各論文は出来次第郵送しなさい，また既発表の論文 で参考論文になりそうなものも郵送しなさい。論文が全部完 成した後に，もう一度会うことにしょう.』と仰いました。

最後の実験についてこ意見が聞けなかったことは，残念で はありましたが，鬼にも角にも後は論文を書くだけというこ とにほっとした気持ちで, 先生のお部屋を辞しました.

2.10 論文の作成

英語の論文は, 語学の得意な辻君(俊郎, 後日本電気株式会 社中央研究所材料研究部長, NEC環境エンジニアリング株式 会社社長, 現戸田工業株式会社取締役)に英文作成に協力して 
もらいました。特に高抵抗薄層が結晶粒界に存在するモデ で解析した論文 ${ }^{2)}$ は，过君が計算を担当してくれ内容を良く 知っていましたので，この点に力点をおいてと指示しただけ で，日本文を示さず，直接英文にしてもらい，出来た後で多 少の修正を指示しただけでした. 奇与度から考えて当然过君 との連名とすべき論文でしたが, 学位請求の主論文でしたの で，辻君には我慢して貴いました。

殆どの論文は，実験事実を整理して若干の考察を加え，緒 言と結論で体裁を整えれば良かったので，作成にあまり時間 を必要としませんでしたので，これらの論文は出来次第先生 のところへ郵送しました。

しかし, 主論文の第二部として『粉体および粉末治金』へ投 稿する予定の「フェライトの粒界析出物と電気抵抗(第二報)」 の作成は難航しました. 考察を進めようとすると，それまで に実験した結果だけではどうしても論理が繋がらず，その間 隙は推測で補う外ないところが幾つか出てきました．以前の 私なら，何の踰躇もなく推測を交えて論を進めたでしょうが， 短期間ではありましたか，岩瀬先生にこ指導を受けた後の私 にはそれが許せませんでした。結局，(ネフェライトの研究の 時には当然のように省略しであろう)明らかに結果が予測され る(と思われた)実験もきちんと補足実験しました. その結果 「フェライトの粒界析出物と電気抵抗(第二報)」を速達で発送 した後,ご都合を伺い, 東京で先生にお目に掛かったのは4月 の下旬になってしまいました.

苦心して書いた「フェライトの粒界析出物と電気抵抗(第二 報)」は赤鉛筆だらけの惨憘たる状態でした．液相㜔結に関す る部分は実験デー夕を含めて全文削除，半導体に関する部分 も実験デー夕を含めて殆ど全文削除され，こく一部が残るだ け，そのほか考察結論の部分の語句は殆ど全部修正という状 態でした.

先生は、『論文を発表する目的は二つある、第一は自分の仕 事を人に知らせること事で、第二汢この分野の什事仕非常に 面白くまだまだ興味ある什事が山にど残っていることを人に 知らせ，この分野に後進を誘うことにある、第一の且的は誰 でも知っているが，あまり人が言わない第二の目的の方が本 来岋重要である。その為には，誰某加通った後は草一本生え ていないと言われるような論文は書くものでない，削除した のはその意味で、今後のこともあるから良く考えておきなさ い、』また『考察結論の部分に，…‥だ，……である，……に 違いない，という言葉加多数ある，実験の結果を記すのには この樣な用語を用いても良い，しかし，わずかな実験しかし ていないのに，考察結論の部分にこの様な断定的な言葉を使 うのは人閒として不抙であるここの様に断定できるのは神样 だけだ，人間は神様ではない，今後注意しなさい』』とも仰い ました.

その他の論文は，断定的な言葉を使うのは人間として不遜 という意味での語句修正が多少あっただけでした.

先生のところから戻り, 早速論文の修正に掛かりました. 主論文の第二部の「フェライトの粒界析出物と電気抵抗(第
二報)」の修正は，かなりの困難が予想されますので後回しと して，まずその他の論文の修正に着手し，修正の終わった論 文は先生に郵送しました。

予想通り「フェライトの粒界析出物と電気抵抗(第二報)」の 修正は難航しました.何しろ目玉というか最も中心であった， 液相焼結に関する部分は実験テータを含めて全文削除，半導 体に関する部分も実験データを含めて殆ど削除でこく一部が 残るだけという状況でしたから，修正というよりは書き直し でした.

何とか辻襟が合うように論文》を仕上げて，次に先生にお 目に掛かったのは 5 月の終わりでした。このときも，全く無 傷という論文はありませんでしたが,修正が終わった論文は, 改めて見せる必要はないから，そのまま投稿するようにとの お言葉でした. 問題の「フェライトの粒界析出物と電気抵抗 (第二報)」は先生が投稿の手続きをして下さるとのことで,お 願いしました。

\subsection{1 論文審查請求・教授会・学位授与}

6月下旬になって，岩瀬先生から，『学位論文審査の請求を しなさい，具体的な手続きについては可知君高田君と相談し なさい.』との電話がありました.

高田先生に手取り足取り細かいことまで教えて戴いただけ でなく，必要な書類の準備までして戴いて，論文審查請求を 終ったのは，6月も未のことでした.

秋には，論文審查のための理学部教授会に呼ばれました。 教授会では，主查をして下さった可知先生が学位申請論文の 内容要旨を，既に配布されている試料に基ついて説明され， 続いて各教授方の質問に私が答えるという段取りでしたが， 可知先生の説明の後,『大変なお仕事ですが, 随分かかったで しょうね.』，という質問がありました．まさか半年と答える 訳にも参りませんから，『はい，かなりかかりました.』とお 答えしました.他に質問がありませんでしたので，そのまま， 教授会から退席しました。

夜，高田先生とお酒を飲んでいる席に，後から合流された 可知先生から『教授会は, 通った.』と聞かされて, 後はお祝 いの会になりました．席上，昼間の論文内容の要旨か簡にし て要を得た見事なものでありましたので，可知先生がお書き になられたのか?と賢問しましたら，筆者は高田先生という ことでした. 高田先生が書かれた原稿を岩瀬先生にお見せし た時, 岩瀬先生は、『手を入れるところが, 全く無いではない か.』とご不満のこ様子であった，とのお話が出て，岩瀬先生 の岩瀬先生らしいご一面を知りました。

昭和 37 年 2 月, 京都大学で理学博士の学位を授与されました。 後年, 亡くなられた岩瀬先生の遺品を整理された高田先生 から，先生のノートに学位の面倒を見られたお弟子さんの名 を列挙された末尾の行間に明石雅夫の名が追加記入されてい たことを知らされました、『おっちやんは君を最後の弟子と考 えておられたらしいよ.』という高田先生のお言葉でした. 有 難いことです。

学位を戴いた直後に，尊敬していた先輩から，『おめでと 
う.』の祝詞に続いて，『どのくらい掛かった？』という質問 を受けました.『確か7,500 円でした.』と答えましたところ， 『それは論文審查の手数料だろう.聞いているのは, 先生方に いくらお礼のお金を包んだかということだよ。といわれまし た.『え…，お金のお礼をするんですか.』という私に，先輩 は『君はお礼もしなかったのか.』と呆れられました. 高田先 生に，『お金でお礼をするのが習慣か？』と伺いましたが，高 田先生は『そんな習慣はない.』とのことでしたので，そのま まにしています．しかし，岩瀬先生をお訪ねする時くらい手 土産の一つも持っていくのが礼儀だったかなあと考えたり， そんなことをすれば岩瀬先生は烈火のことくお怒りなられた だろうと思ったり，末だに判断がつきません.

\section{3 終わりに}

以上長々と学位論文作成の経過を書きましたのは, 岩瀬先

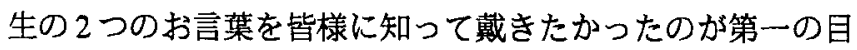
的です.

そのお言葉の一つ『論文を発表する目的は二つある，第二 は自分の仕事を人に知らせることで，第二はこの分野の仕事 は非常に面白くまだまだ興味ある仕事が山ほど残つているこ とを人に知らせ、この分野に後進を誘うことにある，第一の 且的は誰でも知っているがあまり人が言わない第二の且的 の方が本来は重要である，その為には，誰某か通った後は茥 一本生えていないと言われるような論文は書くものでない。 削除したのはその意味で、今後のこともあるから良く考えて おきなさい、』は，正直に言えば当時は非常に不満でした. 学 位論文を指導して下さっている岩瀬先生のお言葉なので, 止 むを得ず，不承不承，液相焼結に関する部分の実験デー夕を 含めて全文削除，半導体に関する部分もごく一部を残し実験 データを含めて殆ど削除を行いました.

後年, 高田先生から『坂東君(その頃は, 会えば挨拶をする 程度の交際しかなかったので, 当時の地位は不明, 後京都大 学教授・名誉教授・当協会 14 代会長, 現岡山理科大学教授) が, 液相焼結について非常に良い仕事をした。』と何いました。

あの時不完全な形で液相焼結に言及していたとすれば，坂 東先生の液相焼結の研究は実施されなかったかもしれないこ とを思えば,岩瀬先生のお言葉はこのことを言われたのだと， 改めて得心したことがありました. (後に, 液相烵結に関する 坂東先生の初期の論文 2 篇に, 先生と連名で明石の名が記載 されていたことを知りました。この2論文で先生に協力した 事実は全くありませんから，坂東先生がこ自分で明石を連名 とされる筈はありません. 何方かが明石を連名とするよう坂 東先生に強要し, 坂東先生が嫌々それに従い明石を連名とし たとしか考えられません，液相焼結について明石が仕事をし たことをご存じなのは岩瀬・高田の両先生お二人だけです. お二人のうちの何方がそのようなことをしたのか坂東先生に お尋ねしたことがありましたが，坂東先生は記憶にないとの ことなので，今となっては調べようもありません．)

岩瀬先生を良く知っている方に, 先生のこのお言葉の話を
致しました時『自分では，岩瀬が通った後は草一本生えてい ないと言われるような論文は書いておきなからら，…․』とい う方が居られました. 先生もお若い時にはこのお言葉とは 違っておられたのかもしれません，しかし，晚年この様にお 考えになられていたことは間違いありません. 若い人に先生 のお言葉のようにせよというのは或いは無理かもしれません. しかし，ある程度世間での評価も定まり相応の地位も得られ た方が論文を書かれるときには，先生のこのお言葉を噒み締 めて戴きたいと存じます.

フェライトの電気抵抗を半導体の見地から追及した研究は， その後もないと思っています。液相焼結の場合のように全文 削除でなく，図一枚, 4行ほどの説明が残ったことがかえって 良くなかったのではないかなどと考えたりしています.

先生の第 2 のお言葉『考察結論の部分に，…..だ，…..で 西る、……違いない，という言葉が多数ある、実験の結果 を記すのにはこの様な用語を用いても良い，しかし、すずか な実験しかしていないのに，考察結論の部分にこの様な断定 的な言葉を使うのは人間として不珎である。この様に断定で きるのは神样だけだ，人間は神様ではない，今後注意しなさ い』』を忠実に守って書いた論文は，可知先生に『蚤の金玉を 八つ裂きにして顕微鏡で䙼いたような実験をした上で，では あるまいかという小憎らしい論文だ.』と言わせる論文になり ました.学位論文だけでなく, 以後何かを書く場合に常に『人 間として不遜』という先生のお言葉を思い出し，部下後輩の 書いたものを見るときにも，同様な注意を部下後輩にするよ う心掛けてきました。

この解説を書いた第二の目的は，ネフェライトの研究と学 位論文のための研究を経験して，堂間としての研究と企業に 必要な研究とは，国じ研究という言葉で表現されてはいます が、全くと言って良い活ど異質だという私の実感を披潾して 皆様のこ意見を戴きたいということにあります.

『研究に多額の投資を続けてきたが，研究の効率加低く，投 資に見合う成果が得られていない.』という大企業経営者の嘆 きを最近良く耳にしますが，大企業の研究指導者と研究者が， 学問としての研究と企業が必要とする研究とは異質であると いうことを, 知らないか, 知っていても軽視していることに， 企業の研究の効率が低い原因の一つがあるように思われてな りません.

現在の大企業の研究指導者と研究者の殆どは大学院の修士・ 博士課程修了者で構成されています.この方々は学問として の研究については充分な知識と経験とをお持ちです.しかし， 学問のための研究と企業が必要とする研究とは異質である。 ということを，大学で教えられた方は皆無でしょうし，企業 に入ってからでもこのことを明確に指導された経験を持つ人 も少ないのではないかと思います。

真理の探究を目的とする学間のための研究は，なぜ? どうして?を追求することから離れることが出来ません， 然しながら，企業が必要とする研究に忳，なぜ?どうし て?を追求することは本質的には不必要なのです。 
研究によって新製品を生み出し，それを販売して利益を得 ることが，研究に投資する企業の目的です．従って有用な新 製品が生まれ，その新製品を安定して量産できる製法が確立 しさえすれば，先ず研究は成功したといえます。牛ぜ新製品 が得られたか?新製品が優九た性能を示すのはなぜか?など ということを知る必要岋企業の研究に㹥全くありません，

新製品やそれを作るための製法・装置・原料の特許を得て， 同業者の追随を振り切ることが出来れば十二分の成果といい 得ましょう. 発明が新規性を持ち(特許法 29 条(1)・29条の 2 . 30条), 進歩性を有し(特許法29条(2), 産業に有用であれば, 特許法は特許発明と認めます. 特許法は, 何をこうしたらこ うなるということやこうなつた結果が産業に役立つという ことについて詳細な説明を要求します.しかし何をこうした らなぜこうなるか？という説明を特許法は一切要求しません， 特許法はなせ役立つものが得られたのかが分からなくても， 役立つものを得るために何をどうすればということが明らか ならばそれでよいのです，その意味からもなぜ？存追求する 必要屾企業の研究にはありません，

間違って作った試料を捨てるのはもったいないと実験した ことが新発見・ノーベル賞に盤がったとノーベル賞を戴かれ た田中耕一さんが話されたことを新聞紙上で知りました.田 中さんは新発見を特許にされたそうですが，間違って作った 試料がなぜたんばく質の質量の精密測定に有用なのかという 根拠を明らかにした上で特許出願をされたのか，それともそ のようななぜの追求は後回しにしてこうすればたんぱく質の 質量の精密測定が出来るということだけで特許出願をされた のか，知りたいものです．ノーベル賞に繋かるような新発見 ですから，企業としては特許の成立を急いだはずで，特許法 上では必要のないなぜの追求は後回しにしてこうすればたん ばく質の質量の精密測定が出来るということだけで特許出願 をされたと思うのですが.

企業の研究になぜ?どうして?の追及を絶対にしてはなら ないといっているのではありません。なぜ?どうして?の研 究を必要最小限度にとどめるのが，研究速度を早め研究効率 在高めるために必要だといいたいのです。

ネフェライトの研究でなぜ?どうして?と考えたことが三 度ありました.一つは高純度原料では電気抵抗が低く椇失か とてつもなく大きい $\mathrm{MnZn}$ フェライトしか得られなかった時 で, $\mathrm{CaO}$ 添加効果の発見で乗り越えました.二つつ目は $\mathrm{CaO}$ 添加しているのに，損失特性が良いもの悪いものが出来て安 定しなかった時で， $\mathrm{CaO} \cdot \mathrm{SiO}_{2}$ 同時添加効果の発見で乗り越え ました. (詳細は本誌 48 巻 10 号「ネフェライト」) 三つ目は 量産に用いる混合装置開発のため, 装置大型化のための実験 中のことでした．量産用混合装置の処理量は実験用の 10000 倍以上が必要でした. 実験用ポットの30倍の処理量では問題 は何も無かったのですが，実験用ボットの1000倍の処理量で はどうしても実験の場合のような混合が出来ません．この時 は新しい管理項目を調節出来るように装置を改造して乗り切 りました。この新しい管理項目について触れている論文書物
は管見の限り当時はありません.その後実験用ポットの10000 倍の処理量のボールミルを設計製作しましたが，全く問題は ありませんでした。

ネ乙ェライトの研究で，なぜ?どうして?を考えた以上三 つの場合は，いずれも従来の知識と研究の結果からでは。二 歩も前に進めない壁に笑当つた時に，打開策を求めるためで 上たそこして，その対策が得られた後は，それ以上のなぜ? どうして?の追及は致しませんでした。

ネフェライトの研究が完了し，全体がある程度明らかに なっていた後でさえ, $\mathrm{CaO} \cdot \mathrm{SiO}_{2}$ 同時添加効果のなぜ？どうし て?を追及するための岩瀬先生の宿題を消化するために, 10 人に近い研究員と 30 人を超える研究補助員を抱えるフェライ 卜研究グループの半年に及ぶ献身的な協力が必要でした。

3人でスタートし,まだ弱小であったネフェライトの研究グ ループか，途中でなぜ?どうして？の追求に走ったならば， 恐らくネフェライトの研究は途中で挫折し，完成することは 無かったでしょう。

学問のための研究と企業の必要とする研究の違いは，な ぜ?どうして?を徹底的に追求するか，速度を重視してな ザ?どうして?の研究を必要最小限度に止めるかにあるとい うのが結論です，企業が必要とする研究には、なぜ?どうし て?を追求することは本質的には不必要といったのは，両者 の差異を鮮明にするために，敢えて强調した極論です．

長くなりましたので, この辺で筆をおきます.最後になり ましたが，岩瀬先生の深いこ恩に感謝の意を表すると共に， 高田先生の的確なこ助言と可知先生のお骨折りに感謝いたし ます. また岩瀬先生の宿題に答えるための膨大な実験に献身 的な協力を惜しまなかった当時の部下の方々に改めて有難う と申し上げます．

\section{文献}

1) T.Akashi: "Effect of Impurities on Grain-Boundary of Ferrites and their Electrical Resistivities (Part I)", J. Jpn. Soc. Powder Powder Metallurgy, 48(1961)101-112.

2) T.Akashi: "Effect of Impurities on Electrical and Dielectric Properties of Manganese Zinc Ferrites", OYO BUTURI, 30(2) (1961)

3) T.Akashi: "Electrical Resistivity of the Grain Boundary in $\mathrm{Mn}$ Zn Ferrite", OYO BUTURI, 30(9)(1961).

4) T.Akashi and Y.Onoda: "Autoradiograph of $\mathrm{Mn}-\mathrm{Zn}$ Ferrite Slightly Doped by ${ }^{45} \mathrm{CaO}$ ", OYO BUTURI, 30(8)(1961).

5) T.Akashi: "Effect of Impurities on Grain-Boundary of Ferrites and their Electrical Resistivities (Part II)", J. Jpn. Soc. Powder Powder Metallurgy, (1961)195-209.

6) T.Akashi: "EFFECT OF THE ADDITION OF CaO AND $\mathrm{SiO}_{2}$ ON THE MAGNETIC CHARACTERISTICS AND MICROSTRUCTURES OF MANGANES-ZINC FERRITES $\left(\mathrm{Mn}_{0.68} \mathrm{Zn}_{0.21} \mathrm{Fe}_{2.11} \mathrm{O}_{4+\delta}\right) "$, TRANSACTONS OF THE JAPAN INSTITUTE OF METALS, (1961). 